\title{
Newman Prosedur Dalam Menganalisis Kesalahan Siswa SMP Dalam Menyelesaikan Soal Setara PISA
}

\author{
Susanti $^{1, \text { a) }}$ \\ ${ }^{1}$ UIN Ar-Raniry Banda Aceh \\ a) susanti@ar-raniry.ac.id
}

\begin{abstract}
This study aims to identify students' errors in solving problem equals to PISA's based on Newman procedures. Qualitative-descriptive research was used in conducting this study and the subjects were third grade students at SMP UnggulSigli in year 2017/2018. Data was collected using tests and interview. The instrument of this study was a sheet consisting of 5 (five) mathematical questions that composed equivalent to PISA's problem. Analyzing students' errors was guided by analyzing procedures developed by Newman which contain 5 (five) kinds of error, they are: (1) reading error; (2) understanding error; (3) transformation error; (4) processingskill error; and (5) writing error. The result showed the percentage of each kind of errors made by students which detailed as follows, reading error comprised $37,1 \%$ of students; error in problem understanding made up $47 \%$; $73 \%$ of subjects made error in transforming; $80 \%$ of students had error in processing; and error in writing final answer made up $78,1 \%$ of them. By analyzing the percentage, it is identified that the three most common mistakes are processing error, transformation error, and error in writing final answer.
\end{abstract}

Keywords: error analysis; test equivalent to PISA's problem; Newman prosedure

\begin{abstract}
Abstrak. Penelitian ini bertujuan untuk mengindentifikasi kesalahan siswa dalam menyelesaikan soal setara PISA berdasarkan Newman prosedur. Jenis penelitiannya adalah penelitian kualitatif deskriptif, subjek dalam penelitian ini adalah siswa kelas IX SMP Unggul Sigli. Teknik pengumpulan data yang digunakan adalah tes dan wawancara. Instrumen penelitian menggunakan soal tes matematika serara PISA yang terdiri dari 5 soal. Analisis kesalahan siswa berpedoman pada analisis yang dikembangkan oleh Newman yang terdiri dari 5 jenis kesalahan yaitu kesalahan membaca, kesalahan memahami masalah, kesalahan transformasi, kesalahan ketrampilan proses, dan kesalahan penulisan. Hasil penelitian diperoleh besarnya persentase tiap jenis kesalahan dari 5 soal yang diberikan yaitu 37,1\% siswa melakukan kesalahan dalam membaca, 47\% terjadi kesalahan dalam memahami masalah, 73\% kesalahan dalam menstransformasi, $80 \%$ kesalahan dalam kemampuan memproses dan 78,1\% kesalahan dalam menuliskan hasil akhir. Dari persentase tersebut dapat diketahui bahwa kesalahan terbesar terjadi pada kesalahan dalam memproses, kesalahan transformasi, kesalahan dalam memahami masalah dan kesalahan dalam menuliskan hasil akhir.
\end{abstract}

Kata kunci: analisis kesalahan; soal matematika setara PISA; prosedur Newman 


\section{PENDAHULUAN}

Matematika merupakan salah satu bidang ilmu yang penting untuk dipelari, sehingga matematika dibelajarkan dari tingkat dasar sampai keperguruan. Matematika sangat erat hubungannya dalam kehidupan sehari-hari, banyak permasalahan dalam kehidupan sehari-hari dapat diselesaikan dengan menggunakan matematika.

Selain itu matematika merupakan salah satu bagian dari ilmu pendidikan yang mendasari perkembangan teknologi modern, mempunyai peran penting dalam berbagai disiplin ilmu, dan memajukan daya pikir manusia. Oleh karena itu, setiap orang diharapkan menguasai matematika sehingga mampu menghadapi tantangan masa depan dalam persaingan global untuk proses pengambilan keputusan (decision making) dalam pemecahan masalah sehari-hari. Kemampuan matematika adalah kemampuan yang dibutuhkan untuk melakukan berbagai aktifitas mental, berpikir, menelaah, dan memecahkan masalah dalam menyelesaikan soal-soal matematika. Kemampuan matematika pada umumnya dikategorikan menjadi kemampuan matematika tinggi, sedang, dan rendah. Kemampuan-kemampuan tersebut antara lain kemampuan pemahaman konsep, kemampuan penalaran, kemampuan koneksi, kemampuan komunikasi, kemampuan representasi, dan kemampuan pemecahan masalah (Putra, Syarifuddin, dan Zulfah, 2018). Selain itu terdapat kemampuan tingkat tinggi yang harus dicapai seperti kemampuan berpikir kritis, kemampuan berpikir kreatif, kemampuan berpikir logis dan lainnya.

Indonesia merupakan salah satu negara yang terlibat dalam Programme for International Student Assessment (PISA), keterlibatan Indonesia dalam PISA merupakan upaya yang dilakukan oleh Indonesia untuk mengetahui sejauh mana perkembangan program pendidikan di bandingkan dengan negara-negara lainnya di dunia. PISA adalah sistem penilaian internasional yang mengukur kemampuan siswa berusia 15 tahun dalam literasi membaca, literasi matematika, dan literasi sains setiap tiga tahun.

Tes PISA berbeda dengan tes pencapaian hasil belajar lainnya, sebab kebanyakan tes yang ada cenderung mengukur kemampuan siswa dalam mengingat kembali apa yang diajarkan di kelas. Tetapi tes PISA memfokuskan pada kemampuan siswa dalam mengimplementasi apa yang mereka pelajari dalam masalah-masalah yang dekat dengan kehidupan sehari-hari, yang membutuhkan kemampuan berpikir tingkat tinggi, dan pemecahan masalah siswa. Program ini dikembangkan untuk mengukur apakah siswa pada usia tersebut telah menguasai apa yang seharusnya mampu dicapai, serta untuk mengetahui apakah siswa mampu mengaplikasikan pengetahuaan mereka dalam kehidupan sehari-hari.

Berdasarkan hasil PISA, skor literasi matematika Indonesia pada tahun 2015 adalah 386, Indonesia mengalami peningkatan jika dibandingkan dengan skor literasi matematika pada tahun 2012 yaitu 375. Hasil ini menunjukan bahwa Indonesia berhasil naik 11 poin dari skor sebelumnya. Rendahnya kualitas pendidikan di Indonesia tidak terlepas dari proses pembelajaran di sekolah, salah satunya siswa belum terbiasa menyelesaikan soal-soal dengan karakteristik konteks nyata, dan hanya mengerjakan soal-soal yang dicontohkan guru tanpa mengetahui manfaatnya dalam kehidupan sehari-hari. Masih banyaknya siswa mengalami kesulitan dalam memecahkan masalah matematika dan terjadinya miskopsepsi siswa ketika belajar matematika (Mujib \& Suparingga, 2013; Mujib, 2017). Akibatnya banyak kesalahan yang dilakukan siswa ketika di hadapkan pada soal-soal setara PISA. Analisis kesalahan secara mendetail dibutuhkan untuk meminimalisir kesalahan sehingga prestasi belajar matematika dapat ditingkatkan. 
Handayani, dkk. (2014) mengungkapkan jenis-jenis kesalahan yang dilakukan siswa dalam menyelesaikan soal PISA yaitu kesalahan intepretasi bahasa, kesalahan konsep, kesalahan penarikan kesimpulan, kesalahan menggunakan data, dan kesalahan penulisan. Penelitian ini bertujuan untuk menganalisis jenis-jenis kesalahan dan mengidentifikasi penyebab kesalahan yang dilakukan siswa dalam menyelesaikan soal setara PISA.

Metode analisis yang akan digunakan dalam penelitian ini adalah metode analisis kesalahan Newman. Metode analisis kesalahan Newman diperkenalkan pertama kali pada tahun 1977 oleh Anne Newman, seorang guru mata pelajaran matematika di Australia. Newman menyarankan lima kegiatan yang spesifik sebagai sesuatu yang sangat krusial untuk membantu menemukan di mana kesalahan yang terjadi pada pekerjaan siswa ketika menyelesaikan suatu masalah berbentuk soal uraian, yaitu: (1) tahapan membaca (reading), (2) tahapan memahami (comprehension) makna suatu permasalahan, (3) tahapan transformasi (transformation), (4) tahapan keterampilan proses (process skill), dan (5) tahapan penulisan jawaban (encoding) (Singh, Rahman, dan Hoon, 2010).

Prakitipong dan Nakamura (2016) membagi lima tahapan analisis kesalahan Newman menjadi dua kelompok kendala yang dialami siswa dalam menyelesaikan masalah. Kendala pertama adalah masalah dalam kelancaran linguistik atau kebahasaan dan pemahaman konseptual yang sesuai dengan tingkat membaca sederhana dan memahami makna masalah. Kendala tersebut dikaitkan dengan tahapan membaca (reading) dan memahami (comprehension) makna suatu permasalahan. Kendala kedua adalah masalah dalam pengolahan matematika yang terdiri dari transformasi (transformation), keterampilan proses (process skill), dan penulisan jawaban (encoding). Berdasarkan penjelasan tersebut, maka metode ini dipilih oleh peneliti agar dapat mengungkapkan jenis kesalahan yang dilakukan oleh siswa dalam menyelesaikan soal setara PISA secara lebih komprehensif, yaitu dari segi penguasaan linguistik atau kebahasaan maupun pengolahan matematika.

\section{METODE}

Jenis penelitian ini adalah penelitian kualitatif deskriptif yang diperoleh dari analisis hasil jawaban siswa yang digunakan secara langsung untuk mengetahui jenis kesalahan subjek dalam menyelsaikan soal-soal setara PISA berdasarkan Newman Prosedur. Subjek dalam penelitian ini adalah 21 siswa kelas IXB SMPN Unggul yang diberikan soal tes berbentuk PISA yang sudah divalidasi sebanyak 5 soal dalam waktu 80 menit. Dari hasil jawaban subjek kemudian diperiksa dan dikaji masing-masing untuk mengetahui jenis kesalahan berdasarkan Newman prosedur pada setiap pertanyaan yang diberikan. Intrumen yang digunakan dalam penelitian ini berupa soal essay yang berkaitan dengan materi volume balok, aritmatika sosial dan luas persegi.

\section{HASIL DAN PEMBAHASAN}

Penelitian ini dilaksanakan di SMPN Unggul Sigli dan yang menjadi kelas subjek penelitian adalah siswa kelas IXB SMPN Unggul. Peneliti memberikan tes soal serta PISA kepada 21 siswa dengan jumlah soal 5 butir soal essay yang soal tersebut sudah divalidasi. Selanjutnya peneliti memeriksa lembar jawaban subjek untuk mengetahui letak kesalahan yang dilakukan oleh siswa. Setelah memeriksa dan mengetahui hasil kerja siswa, peneliti melakukan wawancara tidak terstruktur kepada 2 siswa yang dipilih berdasarkan hasil jawaban yang tingkat kesalahannya tinggi, 2 siswa yang tingkat kesalahannya sedang dan 2 siswa yang tingkat kesalahannya rendah. 
Wawancara ini bertujuan untuk mengetahui faktor-faktor penyebab siswa melakukan kesalahan dalam menyelesaikan soal-soal setara PISA.

Hasil jawaban 21 siswa yang telah dikaji dengan menggunakan Newman prosedur diperoleh jenis kesalahan yang bervariasi yang dilakukan oleh subjek pada soal setara PISA yang peneliti berikan. Soal yang diuji pada saat penelitian berjumlah 5 soal essay setara PISA yang mencakup materi volume balok, aritmatika sosial dan luas persegi panjang. Berikut ini akan disajikan hasil analisis jawaban subjek terhadap 5 soal yang diberikan dan merujuk pada jenis kesalahan yang dikembangkan oleh Newman prosedur sebagai berikut:

Tabel 1. Hasil Jawaban Siswa

\begin{tabular}{ccccccccccc}
\hline Soal & $\begin{array}{c}\text { Kesalaham } \\
\text { dalam } \\
\text { Membaca }\end{array}$ & $\%$ & $\begin{array}{c}\text { Kesalahan } \\
\text { Memahami } \\
\text { Masalah }\end{array}$ & $\%$ & $\begin{array}{c}\text { Kesalahan } \\
\text { Transformasi }\end{array}$ & $\%$ & $\begin{array}{c}\text { Kesalahan } \\
\text { Kemampuan } \\
\text { Memproses }\end{array}$ & $\%$ & $\begin{array}{c}\text { Kesalahan } \\
\text { Penulisan }\end{array}$ & $\%$ \\
\hline 1 & 5 & 24 & 8 & 38 & 12 & 57,1 & 13 & 61,9 & 13 & 61,9 \\
\hline 2 & 2 & 9,5 & 7 & 33 & 11 & 52,4 & 15 & 71,4 & 13 & 61,9 \\
\hline 3 & 8 & 38 & 10 & 48 & 20 & 95,2 & 20 & 95,2 & 21 & 100 \\
\hline 4 & 15 & 71 & 15 & 71 & 19 & 90,5 & 21 & 100 & 21 & 100 \\
\hline 5 & 9 & 43 & 9 & 43 & 15 & 71,4 & 15 & 71,4 & 14 & 66,7 \\
\hline
\end{tabular}

Berdasarkan tabel 1, terlihat bahwa terdapat pola menarik pada tinggi, diameter, Jari-jari, dan keliling alas Tabung Gordang Sambilan. Dimana setiap bilangannya memiliki selisih bilangan terten Berdasarkan data pada Tabel 1, dari hasil jawaban siswa dapat diketahui bahwa hampir seluruh jenis kesalahan seperti yang dijelaskan oleh Newman prosedur oleh siswa dalam kajian ini yang terdiri kesalahan membaca, kesalahan memahami masalah, kesalahan transformasi, kesalahan ketrampilan proses, dan kesalahan penulisan baik yang terjadi pada setiap soal dengan jumlah kesalahan yang berbeda.

Berdasarkan Tabel 1 dapat diketahui bahwa dalam menyelesaikan soal matematika setara PISA nomor 1 sampai dengan nomor 5 terlihat bahwa kesalahan siswa dalam membaca terjadi paling besar pada soal nomor 3 dan 4, pada soal nomor 1,2 dan 5 juga terjadi kesalahan membaca tetapi tidak terlalu banyak jika dibandingkan dengan soal nomor 3 dan 4 . Subjek banyak melakukan kesalahan membaca pada soal nomor 4 dibandingkan dengan soal lainnya, subjek tidak mampu membaca atau istilah yang terdapat pada soal. Selanjutnya kesalahan yang terjadi pada subjek yaitu kesalahan dalam memahami masalah yaitu subjek belum mampu memahami informasi apa saja yang diketahui dan informasi apa saja yang ditanyakn pada soal secara lengkap. Jumlah kesalahan dalam memahmi masalah paling banyak terjadi pada soal nomor 4 .

Berikut adalah beberapa kesalahan subjek yang dilakukan pada saat menyelsaikan soal matematika setara PISA yang menunjukkan kesalahan membaca dan kesalahan memahami masalah. 


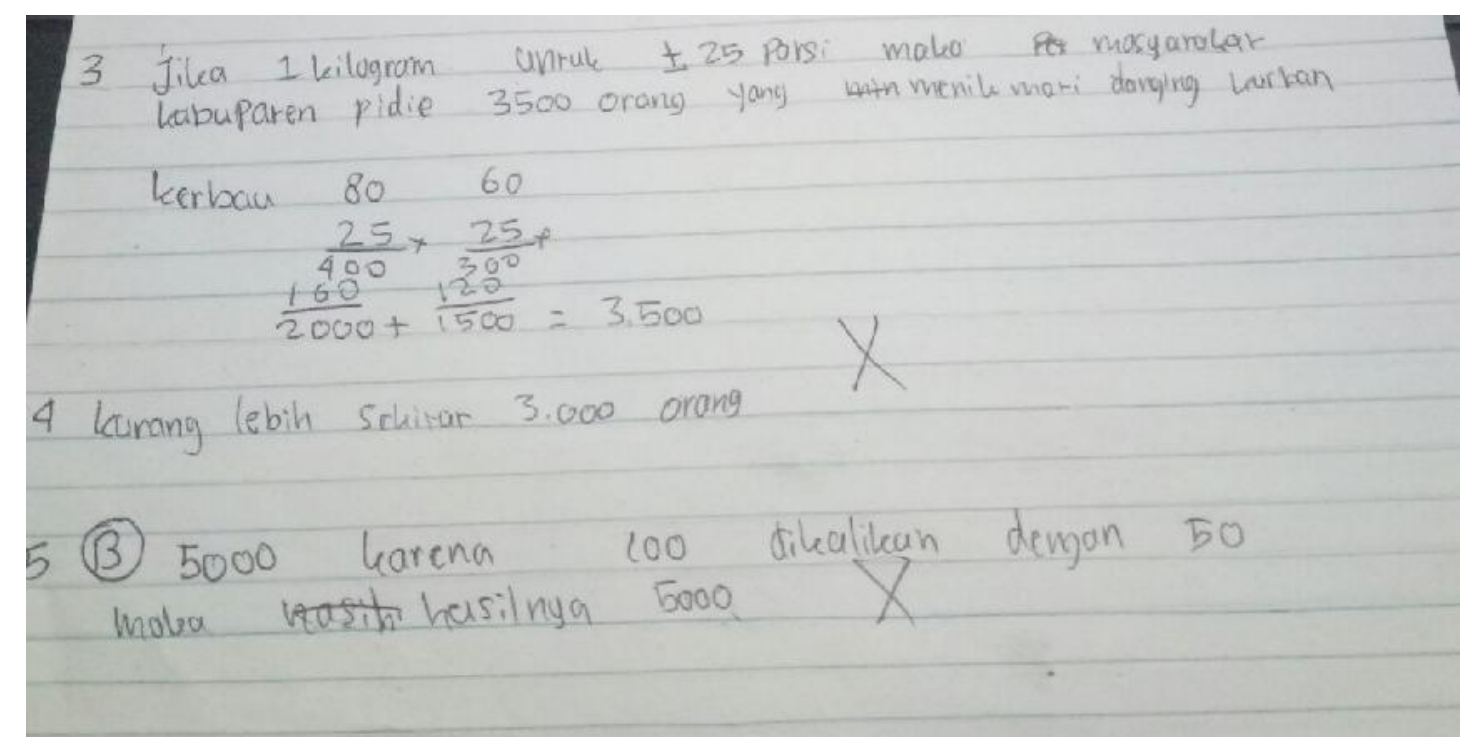

Gambar 1. Jawaban Siswa S 20

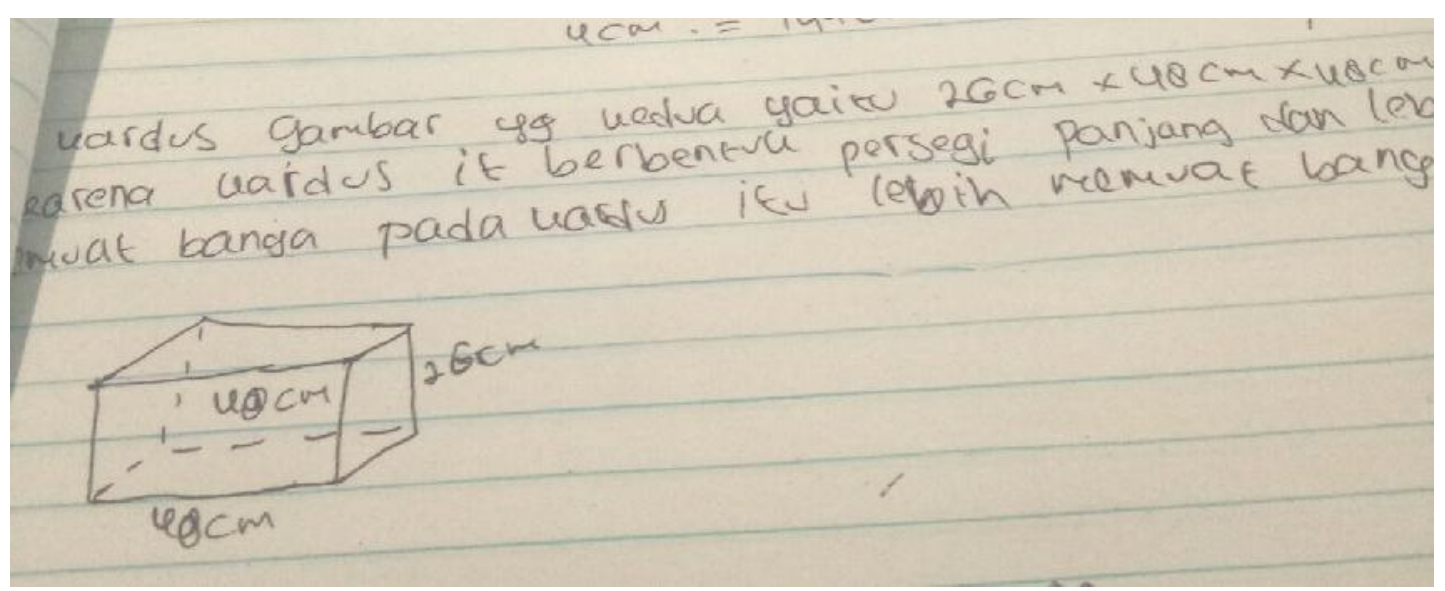

Gambar 2. Jawaban Siswa S 19

Dari Gambar 1 dan Gambar 2 dapat dilihat bahwa subjek dalam menyelesaikan soal matematika setara PISA melakukan kesalahan yang sama yaitu subjek keliru dalam membaca soal dan subjek tidak menuliskan apa yang diketahui dan ditanyakan pada soal tersebut.

Selanjutnya dari Tabel 2 dapat juga diketahui bahwa kesalahan terbesar lainnya yang dilakukan oleh subjek dalam menyelasaikan 5 soal matematika setara PISA adalah kesalahan transformasi dan kesalahan ketrampilan proses. Pada kesalahan ini subjek mampu membuat permaslahan matematika kedalam model matematika serta subjek tidak mampu memilih operasi hitung yang digunakan dalam menyelesaikan masalah matematika. Adapun kesalahan keterampilan proses yaitu pada saat subjek tidak mengetahui prosedur atau langkah-langkah dalam mengindentifikasi masalah yang terdapat pada soal.

Berikut adalah beberapa kesalahan subjek yang dilakukan pada saat menyelesaikan soal matematika setara PISA yang menunjukkan kesalahan transformasi dan kesalahan ketrampilan proses: 


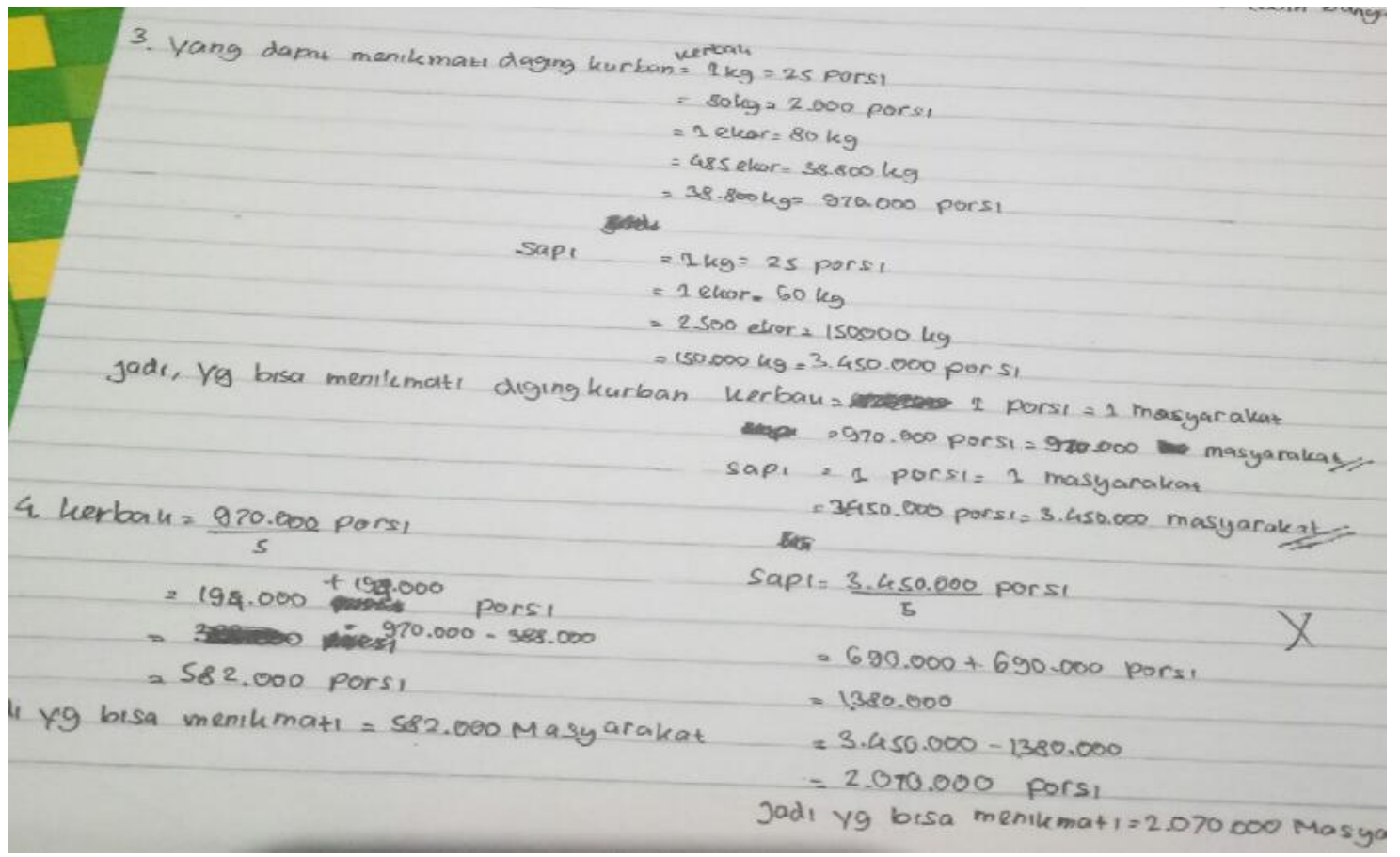

Gambar 3. Hasil Jawaban Siswa S 10

Dari Gambar 3 dapat dilihat bahwa subjek melakukan kesalahan dalam transformasi dan kesalahan dalam ketrampilan proses. Subjek belum mampu membuat model matematika dari informasi yang didapat, tidak mengetahui rumus apa yang digunakan serta tidak mengatahui proses aljabar yang digunakan dalam menyelesaikan soal tersebut.

Selanjutnya jenis kesalahan terakhir adalah kesalahan penulisan, banyaknya subjek yang melakukan kesalahan ini dalam menyelesaikan soal nomor 1 sampai nomor 5. Kesalahan penulisan yaitu kesalahan siswa dalam memberikan atau menunjukkan hasil akhir atau salah dalam menuliskan hasil akhir sesuai dengan kesimpulan. Dari hasil kajian pada Tabel 2 menunjukkan jumlah kesalahan dalam penulisan terbesar oleh subjek yaitu pada soal nomor 4 dan nomor 5 . Berikut akan disajikan salah satu contoh kesalahan siswa dalam menuliskan hasil akhir:

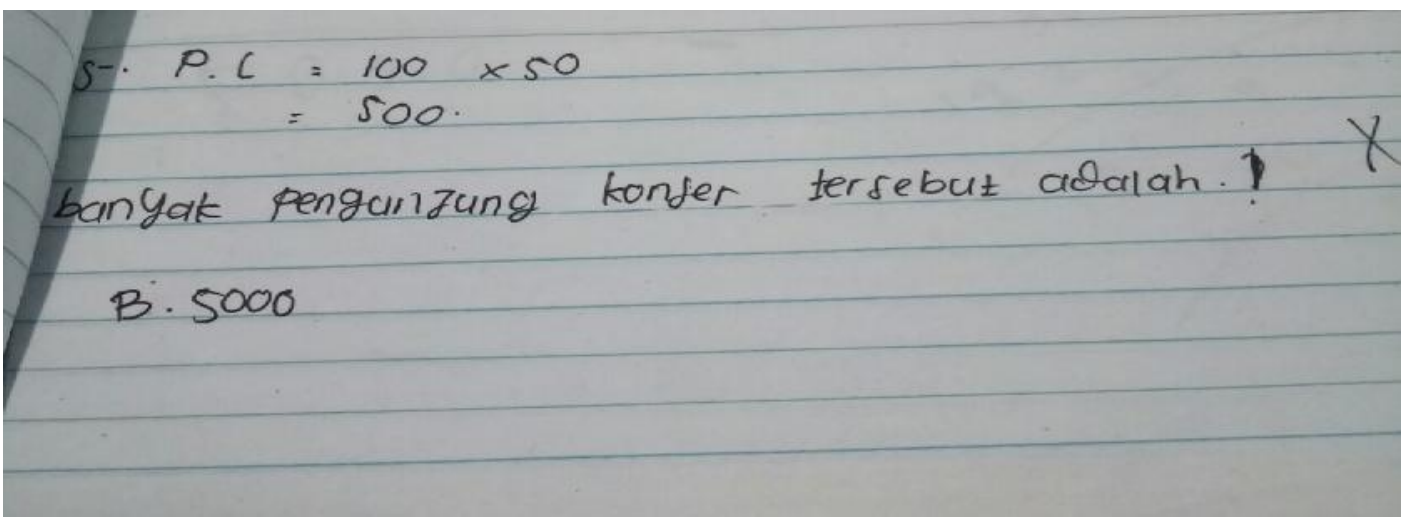

Gambar 4. Hasil Jawaban Siswa S 5

Dari Gambar 4 dapat diketahui bahwa diketahui bahwa siswa masih salah dalam menuliskan hasil akhir, siswa kurang memahami maksud yang ditanyakan pada soal.. 


\section{KESIMPULAN}

Jenis kesalahan yang dilakukan siswa dalam menyelesaikan soal setara PISA dengan Newman prosedur yaitu kesalahan dalam membaca, kesalahan dalam memahami masalah, kesalahan dalam mentransformasikan masalah, kesalahan dalam kemampuan memproses dan kesalahan dalam menuliskan hasil akhir. Dari jenis kesalaha tersebut peneliti memperoleh persentase tiap jenis kesalahan dari 5 soal yang diberikan yaitu 37,1\% siswa melakukan kesalahan dalam membaca, $47 \%$ terjadi kesalahan dalam memahami masalah, $73 \%$ kesalahan dalam menstransformasi ,80\% kesalahan dalam kemampuan memproses dan 78,1\% kesalahan dalam menuliskan hasil akhir. Dari hasil presentase tersebut dapat diketahui bahwa kesahan terbesar terjadi pada kesalahan dalam memproses, kesalahan transformasi, kesalahan dalam memahami masalah dan kesalahan dalam menuliskan hasil akhir.

\section{DAFTAR RUJUKAN}

Handayani, Y., Zulkardi, Z., dan Mulyono, B. 2014. Analisis Kesalahan Siswa dalam Menyelesaikan Soal PISA di SMP Negeri 2 Lahat. Jurnal Edukasi Matematika, 5(10), 682-688

Mujib, A. (2017). Identifikasi Miskonsepsi Mahasiswa Menggunakan CRI pada Mata Kuliah KalkuluS II. Mosharafa: Jurnal Pendidikan Matematika, 6(2), 181-192.

Mujib, A., \& Suparingga, E. (2013, November). Upaya Mengatasi Kesulitan Siswa dalam Operasi Perkalian dengan Metode Latis. Makalah Dipresentasikan dalam Seminar Nasional Matematika dan Pendidikan Matematika.

Prakitipong, N. dan Nakamura, S., 2006. Analysis of Mathematics Performance of Grade Five Students in Thailand Using Newman Procedure. Journal of International Cooperation in Education, 9(1), . 113114.

Putra, A., Syarifuddin, H., \& Zulfah, Z. (2018). Validitas Lembar Kerja Peserta Didik Berbasis Penemuan Terbimbing dalam Upaya Meningkatkan Pemahaman Konsep dan Kemampuan Penalaran Matematis. Edumatika : Jurnal Riset Pendidikan Matematika, 1(2), 56-62. doi:10.32939/ejrpm.v1i2.302

Singh, P., Rahman, A. A., dan Hoon, T. S., The Newman Procedure for Analyzing Primary Four Pupils Errors on Written Mathematical Tasks: A Malaysian Perspective. Malaysian Perspective. 